\title{
Characterization of Gene Encoding Type-I Gonadotropin Releasing Hormone Receptor in Goat (Capra hircus)
}

\author{
Atul Upreti \\ Department of Zoology, Bareilly College \\ Bareilly, (U.P.), India \\ E-mail: atulupreti@gmail.com \\ Vimalkumar Mappilettu Balan \\ Department of Veterinary Biochemistry \\ College of Veterinary and Animal Sciences \\ Pookot, Wayanad, (Kerela) India \\ E-mail: vimalbiotech2000@gmail.com \\ Anjani Kumar Srivastava \\ Indian Veterinary Research Institute \\ Izatnagar, Bareilly, (U.P.) India \\ E-mail: srivastavaak_2004@gmail.com \\ Kamal Kumar Saxena (Corresponding author) \\ Department of Zoology, Bareilly College \\ Bareilly, (U.P.), India
}

Tel: 91-941-260-5965Ｅ-mail: drkamalkumar09@gmail.com

\begin{abstract}
In the present study, complete ORF of GnRH receptor transcript from goat pituitary was amplified, cloned in prokaryotic system and sequenced. The goat type-I GnRH receptor sequence shows high homology with sheep, cow, buffalo, equine and human. Like in other mammalian species in goat too, the GnRH receptor lacks a $\mathrm{C}$ terminal tail. Amino acids which are critical for structure and function of the receptor were found conserved. Few amino acid residues conserved amongst ruminants were found to be replaced in other mammalian species suggesting divergent evolutionary path of this gene in these groups.
\end{abstract}

Keywords: Gonadotropin releasing hormone receptor, Capra hircus, Pituitary, Accession number EF150356 and EU596505

\section{Introduction}

Gonadotropin Releasing Hormone $(\mathrm{GnRH})$ is a key neuroendocrine regulator of the hypothalamic-pituitary-gonadal axis and plays an important role in mammalian reproduction by regulating synthesis and release of gonadotropins. $\mathrm{GnRH}$ is synthesized in hypothalamus and binds to a specific receptor called gonadotropin releasing hormone receptor (GnRH-R) located on plasma membrane of gonadotroph cells of anterior pituitary. In non mammalian vertebrates several subtypes of GnRH and it's receptor are known. In mammals two subtypes of this hormone called GnRH-I and GnRH-II are found, but the only functional subtype of GnRH receptor found in mammals is type-I GnRH-R as in no species a type-II GnRH-R gene lacking a frame shift mutation is reported so far (Millar et al., 2004). Type-I GnRH-R is a member of seven transmembrane domain $G$ protein coupled receptor super-family and is hypothesized to couple to 
multiple G proteins (Conn and Croeley 1994). Unlike other members of this super-family, type-I GnRH-receptor lacks the carboxy terminal tail (Stojilkovic et al., 1994; Sealfon et al., 1997) which participates in several downstream reactions through several receptor-associated proteins (Bockaert et al 2003; Ferguson et al., 2001). GnRH receptor transcripts have also been detected in some extrapituitary tissues, including ovary (Choi et al., 2001; Kang et al., 2000 and 2001) and placenta (Siler-Khodr et al., 2001; Khodr et al., 1980; Chou et al., 2004) and there are increasing evidences that GnRH may act as an autocrine or paracrine factor in regulating local cellular functions in these organs. In the ovary GnRH modulates both basal and gonadotropin-stimulated steroidogenesis (Olofsson et al., 1995) and induces transcription of several genes involved in the follicular maturation process and ovulation. High-affinity binding sites for GnRH-I have been reported in human corpus luteum, luteinized granulose cells, and a number of ovarian cancer cell lines (Bramley et al., 1987; Emons et al., 1989 and 1993; Brus et al., 1997). Though goat is an economically important animal for Asian countries, particularly India, no information is available on GnRH receptor of goat. In the present study, transcript of type-I GnRH receptor has been characterized in goat pituitary. The goat type-I GnRH receptor sequence shows high homology with sheep, cow, buffalo, equine and human. Like in other mammalian species in goat too, the GnRH receptor lacks a $\mathrm{C}$ terminal tail. Amino acids which are critical for structure and function of receptor were found conserved. Few amino acid residues conserved amongst ruminants were found to be replaced in other mammalian species suggesting divergent evolutionary path of this gene in these groups.

\section{Materials and methods}

\subsection{Total RNA isolation}

For total RNA isolation, pituitaries were collected from local abattoir, immediately after slaughter in RNAlater solution (Qiagen, Germany). Total RNA isolation was done using RNeasy Mini kit (Qiagen, Germany) according to manufacturer's protocol. Total RNA was quantified and its integrity was assessed using $1 \%$ formaldehyde agarose gel electrophoresis.

\section{2 cDNA synthesis}

For cDNA synthesis $5 \mu \mathrm{g}$ of total RNA was reverse transcribed into first strand cDNA, using oligodeoxythymidine primers (MBI-Fermantas). Each reaction included 1 X RT buffer $50 \mathrm{mM}$ Tris- $\mathrm{HCl}(\mathrm{pH} 8.3), 50 \mathrm{mM} \mathrm{KCl}, 4 \mathrm{mM} \mathrm{MgCl}$, $5 \mathrm{mM}$ DTT (MBI-Fermentas), $2.5 \mathrm{mM}$ of each of the four deoxy-NTPs, $0.5 \mu 1$ oligo-dT primers, $20 \mathrm{U}$ Ribonuclease inhibitor, and $200 \mathrm{U}$ Moloney murine leukemia virus reverse transcriptase (MBI-Fermentas) and was carried out at a volume of $25 \mu \mathrm{l}$ for $1 \mathrm{~h}$ at $37^{\circ} \mathrm{C}$. Reaction was stopped by heating at $70^{\circ} \mathrm{C}$. A parallel control reaction was carried out without adding reverse transcriptase. After the end of the reaction, the volume was increased to $100 \mu 1$ with ultrapure water, and the mixture was stored at $-20^{\circ} \mathrm{C}$.

\subsection{PCR amplification}

The primers were designed to amplify two PCR products a 408 bp product and a 1026 bp product on the basis of the available bovine and ovine GnRH receptor sequences. Primers used to amplify $1026 \mathrm{bp}$ product were, forward 5'ATAAAGGATGGCAAACAGTGAC3', reverse 5'GCCTTTCTTTGACTTTCTATGC3' and primers for 408 bp product were forward 5'CCT CCC CAC CCT GAC CCT ATC T-3' and reverse 5'GCCAAGCCAATCATGAACTGTCC3'. Standard protocol according to Sambrook and Russel (2001) was used for PCR amplification. Reaction was carried out in $25 \mu \mathrm{l}$ reaction volume containing $70 \mathrm{ng}$ of cDNA, $10 \mathrm{pM}$ of each primer, $400 \mu \mathrm{M}$ of dNTP mix, 2.5 unit of Taq DNA polymerase and $1.5 \mathrm{~mm}$ of $\mathrm{MgCl}_{2}$ using T personal thermocycler. The PCR programme used to amplify $408 \mathrm{bp}$ product involved initial denaturation at $95^{\circ} \mathrm{C}$ for 3 min followed by 32 cycles of denaturation at $95^{\circ} \mathrm{C}$ for $1 \mathrm{~min}$, annealing at $50^{\circ} \mathrm{C}$ for $30 \mathrm{sec}$ and extension at $72^{\circ} \mathrm{C}$ for $1 \mathrm{~min}$ ending with a final extension at $72^{\circ} \mathrm{C}$ for $10 \mathrm{~min}$. Same reaction volumes, conditions of temperature and time were used to amplify $1026 \mathrm{bp}$ product, except that annealing temperature was $48^{\circ} \mathrm{C}$. The amplified PCR products were electrophorized in with $100 \mathrm{bp}$ DNA ladder (MBI Fermentas) on ethidium bromide stained 1\% agarose gel and were visualized and photographed under UV.

\subsection{Cloning and sequencing of PCR product}

Both 1026 and 408 bp PCR products were cloned in prokaryotic system and sequenced. For this PCR products were purified using gel extraction kit (Qiagen) following manufacturers protocol. The purified PCR product was ligated to pTZ57R/T (MBI Fermentas) cloning vector using 50 ng purified PCR products 50ng of vector, and 5U of $\mathrm{T}_{4}$ DNA Ligase. The reaction mixture was incubated at $22^{\circ} \mathrm{C}$ overnight in water bath. The transformation of DH5 $\alpha$ E.Coli cells with ligated product was done using Insta cloning kit (MBI Fermentas) following manufactures procedure. The transformed cells were spread over ampicillin agar plate coated with $40 \mu 1$ of $0.1 \mathrm{~m}$ IPTG and $40 \mu \mathrm{lof} 20 \mathrm{mg} / \mathrm{ml} \mathrm{X} \mathrm{Gal}$. The white colonies were propagated in $3 \mathrm{ml} \mathrm{LB}$ broth containing ampicillin by overnight incubation in a shaker incubator at $37^{\circ} \mathrm{C}$. Presence of insert was confirmed by plasmid isolation using alkaline lyses method followed by restriction digestion with EcoRI and SalI enzymes. For sequencing cloned PCR products, DNA sequencing facility at University of Delhi South Campus (UDSC), New Delhi was availed. 


\section{Results}

\subsection{RNA isolation and RT-PCR}

The RNA yield using RNAeasy mini kit was found $1.5 \mu \mathrm{g} / \mathrm{mg}$ of tissue and 260/280 of the RNA sample obtained was 1.98 indicating the high purity of the RNA sample. (Fig. 1) Primers used for the amplification were designed on the basis of published sequences of bovine and sheep GnRH-R gene. PCR with these primers gave products of expected size i.e. 1026 bp (Fig. 2) and 408 bp products (Fig. 3) from pituitary.

\subsection{Cloning and Sequencing of PCR products}

About 110 colonies were observed on the LB plates. Colonies were screened by blue and white selection method. Most colonies were white and few blue. The white colonies were propagated for the plasmid isolation and further confirmation. Alkaline lysis method was found to be an easy and fast method for plasmid isolation. Isolated plasmid was free from genomic DNA and RNA contamination. The yield of plasmid was $484 \mathrm{ng} / \mu \mathrm{l}$ and has shown a 260/280 ratio of 1.8 which was sufficient for carrying out subsequent screening steps. InsT/A cloning vector has restriction sites for EcoRI and SalI, which were absent in the insert. Therefore for screening of recombinant clones, plasmids isolated from different white colonies were subjected to double digestion with restriction enzymes, EcoRI and SalI. Insert release of about $1026 \mathrm{bp}$ and $408 \mathrm{bp}$ were confirmed by agarose gel electrophoresis. Clones confirmed for the presence of desired fragments were sequenced at UDSE New Delhi. The obtained sequences were analyzed using DNASTAR software. The sequence homology was confirmed using Basic Local Alignement Search Tool (BLAST) programme of National Centre For Biotechnology Information Gene Bank (www.ncbi.nlm.nih.gov). Sequences were submitted to Gene Bank NCBI and Accession number EF 150356 and EU 516505 were obtained.

\section{Discussion}

The amplified 1026 bp product spans complete ORF, which is 987 bp long, position 8 to 994 (Fig. 5) The 408 bp product corresponds to position 81 to 488 of the ORF. The 408 bp product resides completely within the Exon-I region and thus can be used as a probe for type-I GnRH-R gene identification in southern dot blot analysis with RT-PCR product as well as with genomic DNA. The ORF of goat type I GnRH was aligned with that of other mammalian species using MegAlign programme of DNASTAR software. The goat type-I GnRH ORF shows more than $85 \%$ homology with different animal species. The sequence shows high homology with GnRH receptor sequences of sheep (99\%), cow (98\%), buffalo (98.4\%), equine (91.5\%) and human (88.4\%). The phylogenetic tree of type-I GnRH-R gene of different mammalian species show different evolutionary pattern as GnRH-R gene of goat and sheep fall in one group which in turn share close evolutionary resemblance with primate and distinct relation with rodents (Fig. 4). The amino acid sequence of goat type-I GnRH-R bears all the characteristic features for transmembrane receptor. High numbers of hydrophobic amino acid residues (141 out of 328) in deduced amino acid sequence were found, which is a characteristic feature of transmembrane protein. The length of the protein suggests that like other mammalian species in goat too, the GnRH-R lacks a C terminal tail. The deduced amino acid sequence was aligned with that of other species using MegAlign programme (Fig. 6). Upon alignment of the amino acid sequence of type-I GnRH receptor of several mammalian species it was found to be more than $90 \%$ conserved. Goat type I GnRH-R share close similarity with sheep (98.5\%), buffalo and cow (97.9\%) and equine (92.7\%), lower similarity with human and macaca $(89.7 \%$ and $89.9 \%$ respectively) and lowest similarity with mouse and rat (86.0\% and $84.8 \%)$. These results are in accordance with the nucleotide sequence analysis. The putative transmembrane domains were found almost identical with in these mammalian species. Amino acid residues important for receptor function for instance, Ala (261) in the third intracellular loop which is crucial for G protein coupling and receptor internalization ( Myburgh et al., 1998), Asp (98), Trp (101) Asn (102), Lys (121), Asn (212) and asp (302) which are important for ligand binding (Hoffmann et al., 2000) were found conserved in all species. The GnRH receptor was found conserved amongst mammalian species but species wise difference were found at several positions, for example, Ser (27) is well conserved amongst ruminants (cow, buffalo, sheep and goat), but is replaced by Lys in rodents (mouse and rat) and by Asn in human and macaca monkey, residue Ile (51) which is conserved amongst ruminants is replaced by Ala in rodents and Thr in human and macacca. Several such species wise variations were observed in amino acid sequences of Type-I GnRH-Receptor in different mammalian species. These results suggest the divergent evolutionary path of Type-I GnRH receptor in different animal groups. Type-I GnRH-R appears to have undergone a relatively recent period of rapidly accelerated molecular evolution (Fig 4) that may have been important for the development of mammalian reproductive strategies. The present study provide the necessary information about Type-I GnRH-R in goat and paves the way for further molecular work related to this receptor in goat, like PCR based confirmation of expression of this receptor in different tissues and quantitative PCR (real time PCR) to study different expression levels of this receptor.

\section{Acknowledgments}

Authors are thankful to the Director, Indian Veterinary Research Institute, for providing necessary research facilities. 


\section{References}

Bockaert, J., Marin, P., Dunuis, A., Fagni, La. (2003). The 'magic tail' of G protein-coupled receptors: an anchorage for functional protein networks FEBS let, 546:65-72.

Bramley, T. A., Stirling, D., Swanston, I. A., Menzies, G. S., McNeilly, A. S., Baird, D. T. (1987). Specific binding sites for gonadotropin-releasing hormone, LH/chorionic gonadotropin, low-density lipoprotein, prolactin and FSH in homogenates of human corpus luteum. II. Concentrations throughout the luteal phase of the menstrual cycle and early pregnancy. J Endocrinol, 113:317-327.

Brus, L., Lambalk, Cb., De Koning, J., Helder, Mn., Janssens, Rm., Schoemaker, J. (1997). Specific gonadotropin releasing hormone analogues binding predominantly in human luteinized follicular aspirates and not in human pre-ovulatory follicles. Human reproduction, 12:767-773.

Choi, K. C., Auersperg, N., Leung, P.C. (2001). Expression and antiproliferative effect of a second form of gonadotropin-releasing hormone in normal and neoplastic ovarian surface epithelial cells. J Clin Endocrinol Metab, 86:5075-5078.

Chou, C. S., Beristain, A. G., MacCalman, C. D., Leung, P. C. (2004). Cellular localization of gonadotropin-releasing hormone $(\mathrm{GnRH})$ I and GnRH II in first-trimester human placenta and deciduas. J Clin Endocrinol Metab, 89:1459-1466.

Conn, P. M., Crowley, Jr. W. F. (1994). Gonadotropin-releasing hormone and its analogs. Annu Rev Med, 45:391-405.

Emons, G., Ortmann, O., Becker, M., Irmer, G., Springer, B., Laun, R., Hölzel, F., Schulz, K. D., Schally, A.V. (1993). High affinity binding and direct antiproliferative effects of LHRH analogues in human ovarian cancer cell lines. Cancer Res, 54:5439-5446.

Emons, G., Pahwa., G. S., Brack, C., Sturm, R., Oberheuser, F., Knuppen, R. (1989). Gonadotropin releasing hormone binding sites in human epithelial ovarian carcinomata. Eur J Cancer Clin Oncol, 25:215-221.

Ferguson, S. S. (2001). Evolving concepts in G protein-coupled receptor endocytosis: the role in receptor desensitization and signaling. Pharmacol Rev, 53:1-24.

Hoffmann, S. H., ter Laak, T.T., Kuhne, R., Reilander, H., Beckers, T. (2000). Residues within transmembrane helices 2 and 5 of the human gonadotropin-releasing hormone receptor contribute to agonist and antagonist binding. Mol Endocrinol, 14:1099-1115.

Kang, S.K., Choi, K.C. Cheng, K.W., Nathwani, P.S., Auersperg, N., Leung, P.C. (2000). Role of gonadotropin-releasing hormone as an autocrine growth factor in human ovarian surface epithelium. Endocrinology, 141:72-80.

Kang, S. K., Tai, C. J., Nathwani, P. S., Leung, P. C. (2001). Differential regulation of two forms of gonadotropin-releasing hormone messenger ribonucleic acid in human granulosa-luteal cells. Endocrinology, 142:182-192.

Khodr, G. S., Siler-Khodr, T. M. (1980). Placental luteinizing hormonereleasing factor and its synthesis. Science, 207:315-317.

Millar, R. D. B., LU, Z., Pawson, A. J., Flanagan, C. A., Morgan, K. and Maudsley S. R. (2004). Gonadotropin-Releasing Hormone Receptors. Endocrine Reviews, 25(2):235-275.

Myburgh, D. B., Millar, R. P., Hapgood, J. P. (1998). Alanine-261 in intracellular loop III of the human gonadotropin-releasing hormone receptor is crucial for G-protein coupling and receptor internalization. Biochem $J$, 331:893-896.

Olofsson, J. I., Conti, C. C., Leung, P. C. (1995). Homologous and heterologous regulation of gonadotropin-releasing hormone receptor gene expression in preovulatory rat granulosa cells. Endocrinology, 136:974-980.

Sambrook, J. and Russel (2001). Molecular cloning: a laboratory manual. Third edition. Cold spring harbor laboratory predd, cold spring harbour, new york.

Sealfon, S. C., Weinstein, H. and Millar, R. P. (1997). Molecular mechanisms of ligand interaction with the GnRH-R. Endocr. Rev., 18(2): 180-205.

Siler-Khodr, T. M., Grayson, M. (2001). Action of chicken II GnRH on the human placenta. J Clin Endocrinol Metab, 86:804-810.

Stojilkovic, S.S., Reinhart, J., Catt, K.J. (1994). Gonadotropin-releasing hormone receptors: structure and signal tran sduction pathways. Endocr Rev, 15:462- 499. 


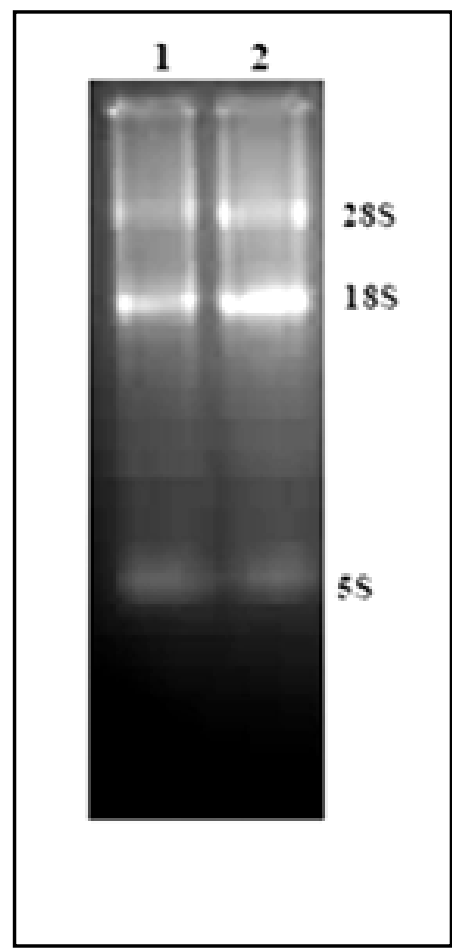

Figure 1. Formaldehyde Agarose Gel electrophoresis of Total cellular RNA from Goat Pituitary

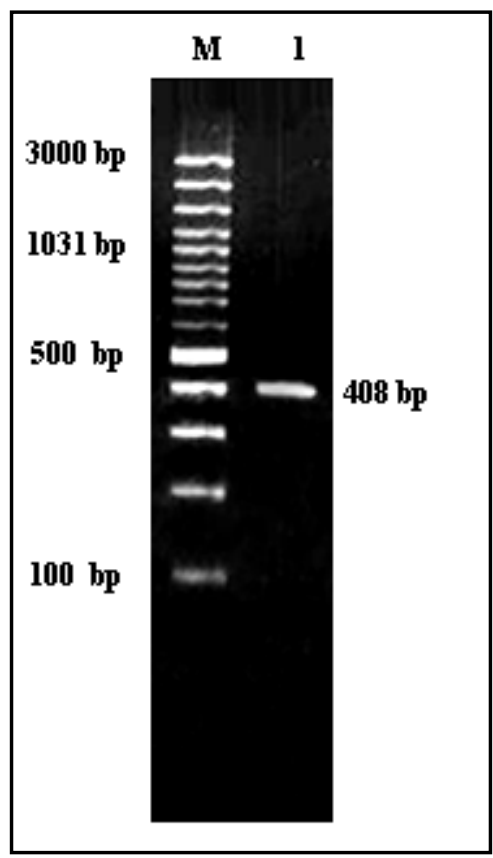

Figure 2. Agarose Gel Electrophoresis of 408 bp purified PCR Product from goat pituitary cDNA. Lane M Molecular size marker, Lane 1 purified 408 bp product 


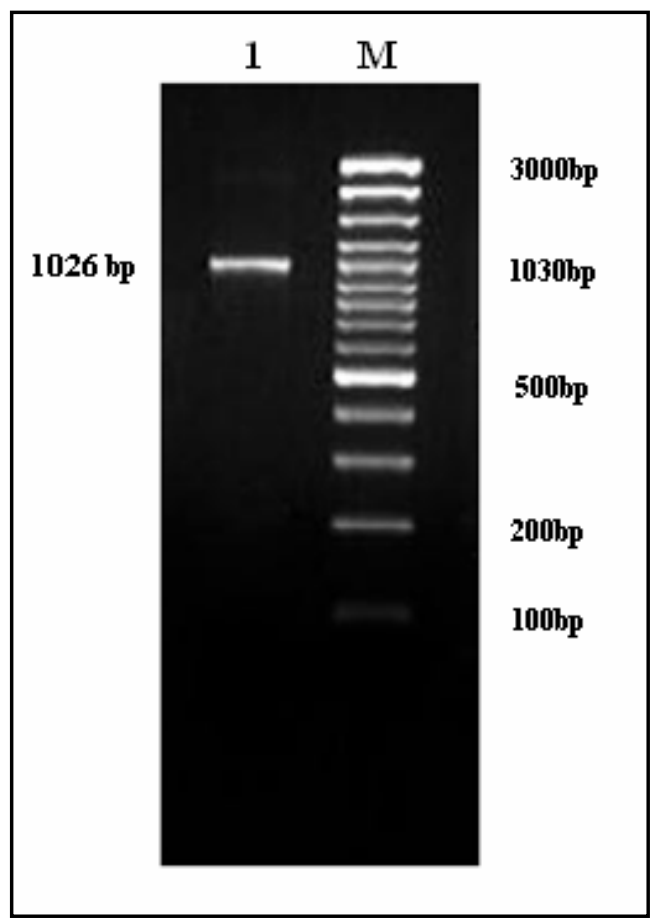

Figure 3. Agarose gel electrophoresis of purified 1026bp PCR product Lane M Molecular size marker, Lane 1 purified 1026 bp purified product

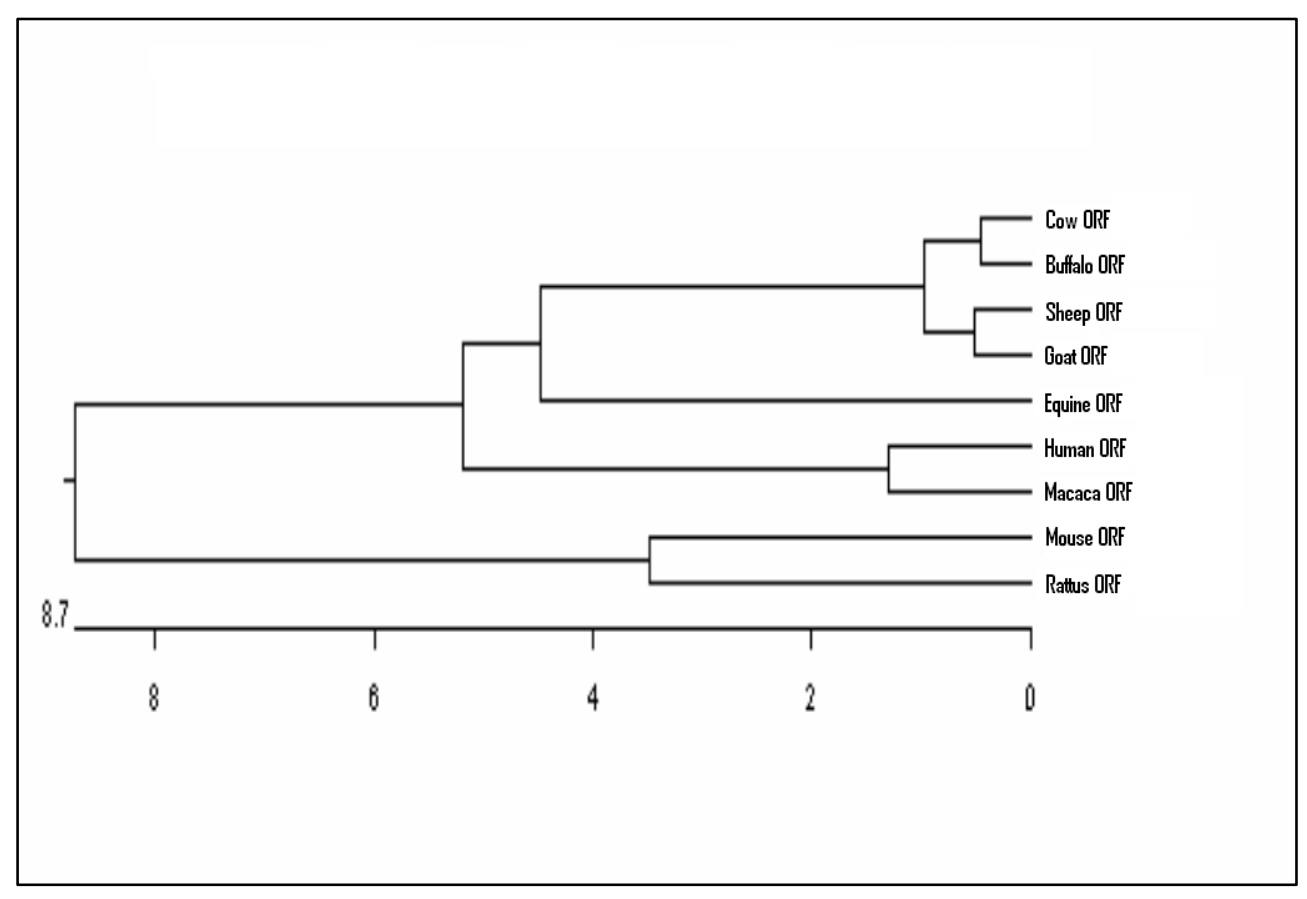

Figure 4. Phylogenetic tree of Type-I GnRH Receptor gene based on the sequences of different animal species 
8 at goc aagagt gact ct cct gaacagaat qaaaccact gt toa

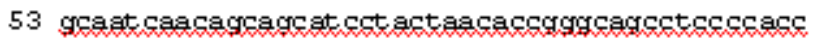

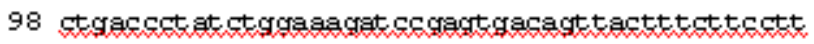

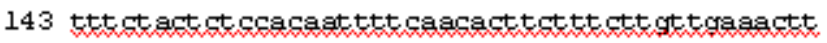

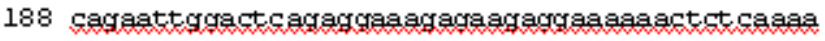

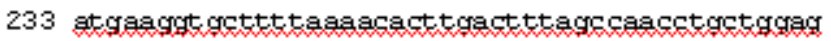

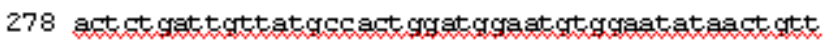

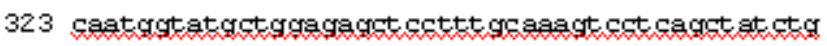

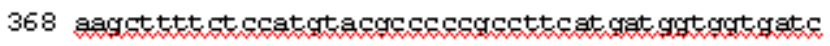

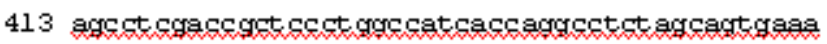

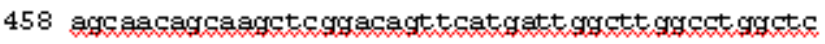

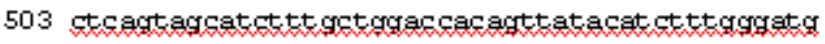

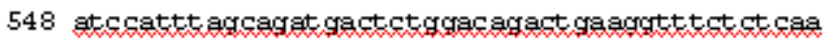

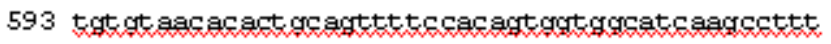

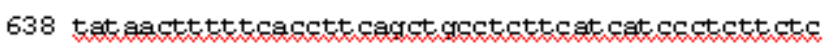

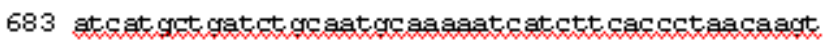

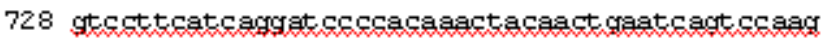

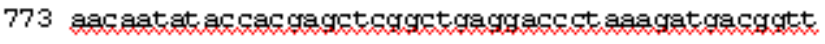

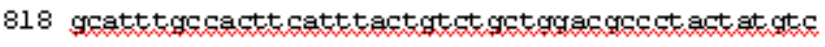

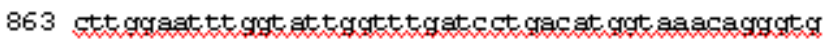

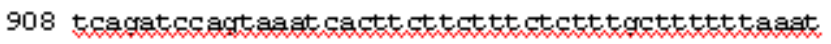

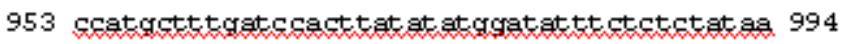

Figure 5. ORF of goat type-I GnRH-R gene 
MANSASPEQRENHCSAINSSIPLTQGSLPTLTLSGKIRUT Majority

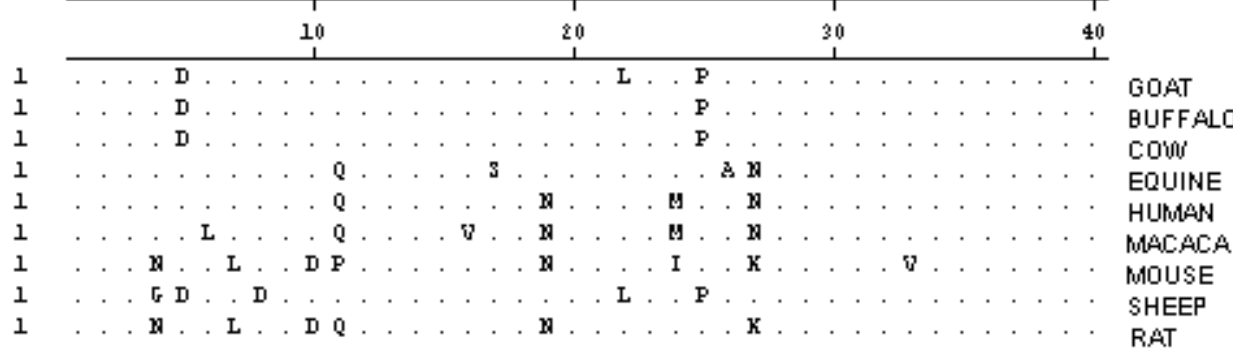

VTFFLFLLSTIFARSFLLKLQNDTQKKEKGKKLSRMKVLL Majority

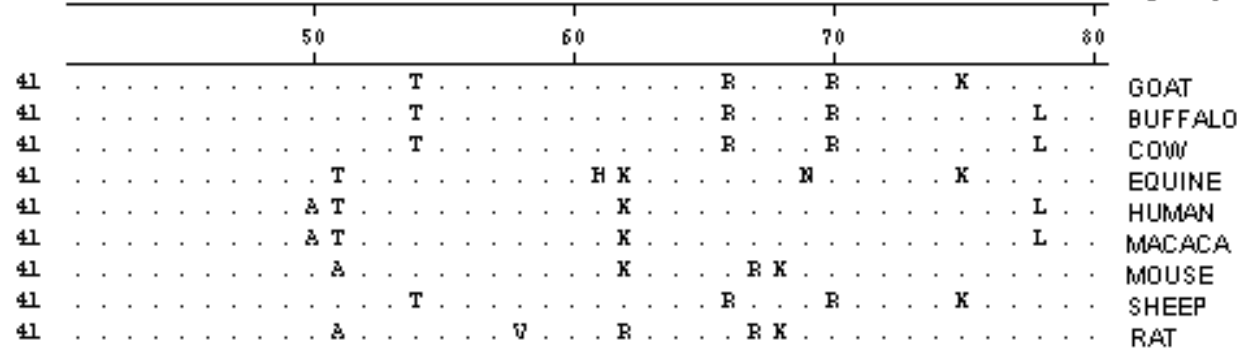

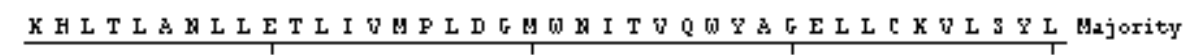

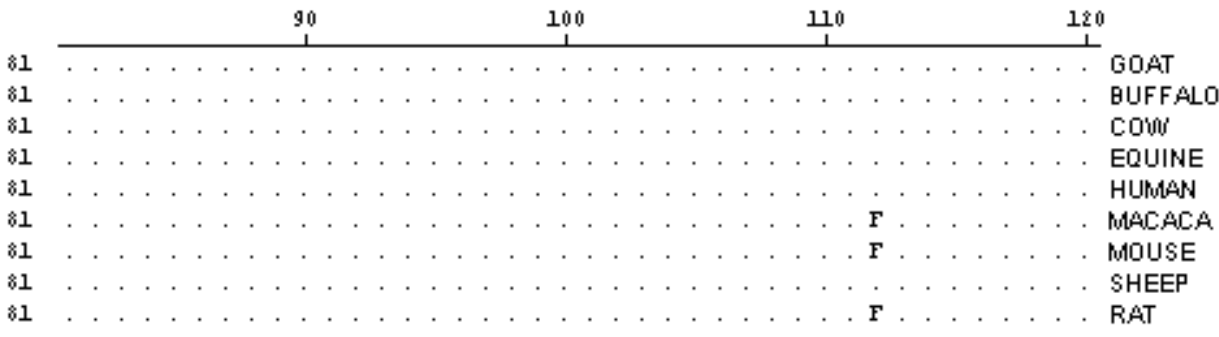

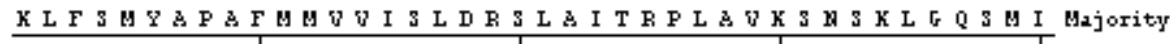

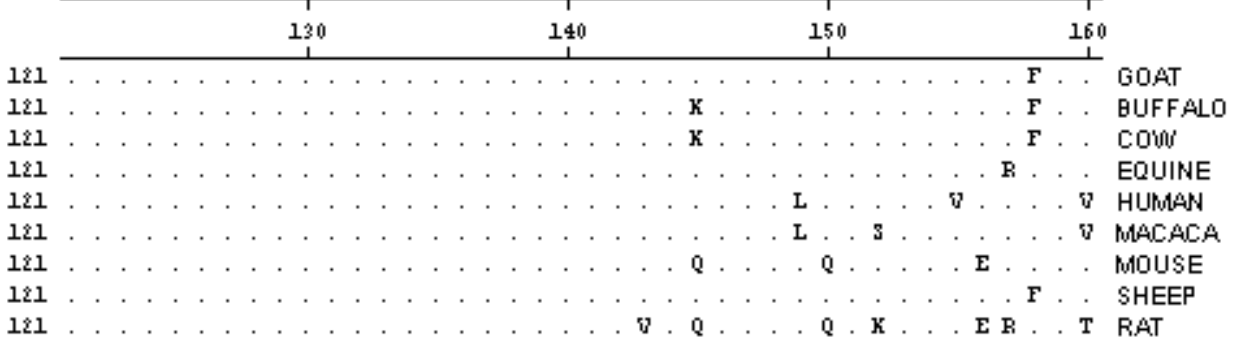

GLADLLSSIFAGPQLYIFEMIFLADES GQTEGFSQCUTHC Majority

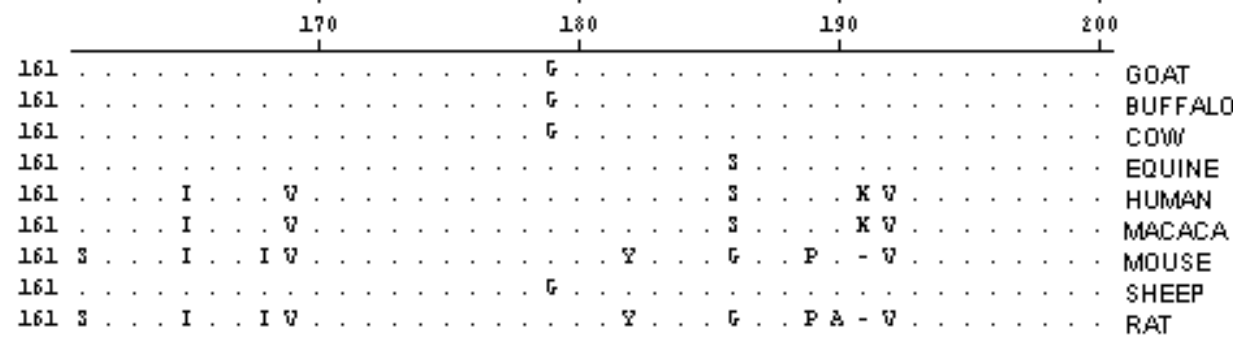

$3 F P Q D W H Q F Y M F T T S C L F I I P L L I M L I C N A K I I F T L T R$ Majority

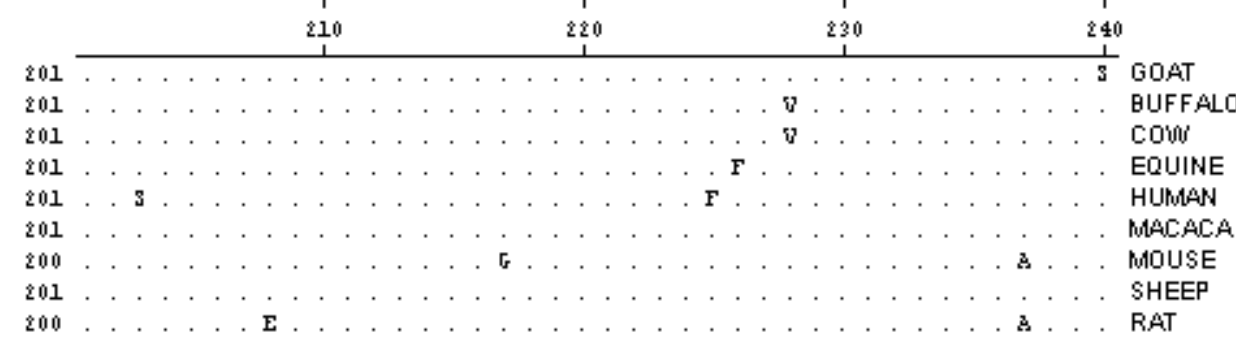




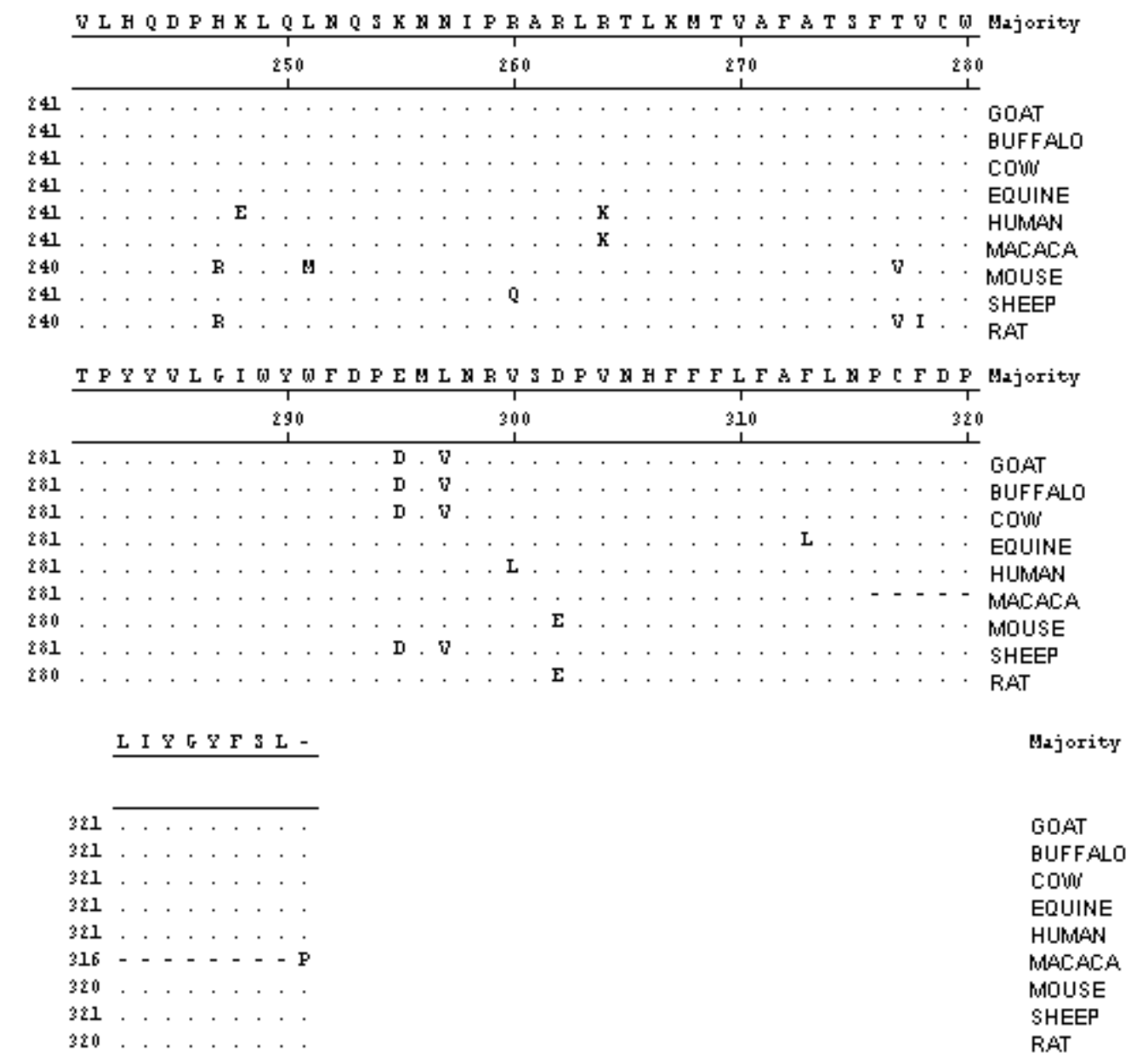

Figure 6. Alignment of goat type-I GnRH-R deducted amino acid sequence with other animals 